\title{
Nation, Empire-State and Nation-State: Beyond Usual Misinterpretations
}

\section{Contemporary Russia and the Legacy of Empires}

\author{
Alexei I. Miller
}

\author{
Alexei I. Miller \\ European University at Saint-Petersburg, Russia \\ Department of History \\ Professor; \\ Center for the Study of Cultural Memory and Symbolic Politics \\ Research Director
}

ORCID: 0000-0001-8139-0976

ResearcherID: Z-1451-2019

Scopus AuthorID: 56321369000

Phone: +7 (812) 386-7634

E-mail: amiller@eu.spb.ru

Address: European University at St. Petersburg, 6/1A Gagarinskaya Str., St. Petersburg 191187,

Russia.

The work on this article was supported by the Russian Science Foundation, grant No. 17-1801589. It is an offspring of the CENTERO project "Modern Empires and Their Significance for Modernity" (https://centero.ru/wp-content/uploads/2020/02/Doklad3_Eng-Internet-2_res.pdf)

DOI: 10.31278/1810-6374-2020-18-2-90-107

\section{Abstract}

A close look at the history of 19th century Europe shows that the most significant nation-building projects were carried out in the core areas of empires and were closely connected with the development of these empires and their place in the global system of inter-imperial rivalry. Nations were created by states, and empires supplied these states with resources. All key elements of modernity-bureaucracy, industrialization, urbanization, etc.-emerged and developed in empires. The Russian Empire was the construction site of 
the Russian nation. The Soviet project of gathering the space which previously belonged to the Russian Empire was inspired by fundamentally different ideas: "Great Russian chauvinism" as the main threat to Soviet power; the denial of the all-Russian nation concept; institutionalization and territorialization of ethnicity; and positive discrimination against non-Russians as compensation for dominance of ethnic Russians in the Russian Empire. The post-imperial character of modern Russia clearly indicates that the imperial legacy tangibly permeates our modern life, its intellectual, institutional, and other dimensions. Attempts to ignore this legacy or drastically "clear out the ruins" will not yield favorable results. The task is to create a design of the future in which its authors will be able to take an unbiased look at the legacy of empires, free from the inherited intellectual restrictions and hackneyed stereotypes.

Keywords: post-imperial Russia, empires and nationalism, nation-state and state-nation, the USSR as an empire

The understanding of the nature of the events that concluded World War I, and generally the political interpretation of the

correlation between empire, nation and nation-state brim with misconceptions which seriously affect our current approaches to key political issues. The notion of nation-state as the only adequate form of political organization during modernity and post-modernity eras is one of the cornerstones of several contemporary ideologies. This is why this misconception is so hard to overcome. This article is an attempt to "free" our view of history, in which the processes of building a state and a nation, we believe, are interconnected in a different and more intricate way than modern national narratives suggest (for a detailed historical analysis of the issues under discussion, see Berger and Miller, 2015). In the end, we will show the importance of this reinterpretation of history for understanding the challenges facing modern Russia.

\section{EMPIRE-BUILDING AND NATION-BUILDING: ENTANGLEMENTS}

The year 2018 marked a centenary of the collapse of four continental empires on the eastern fringes of Europe-Russian, German, Ottoman, and Austro-Hungarian. Their fall at the end of World War 
I is generally believed to have been inevitable and blamed on the fact that empire was an obsolete and backward form of political organization which by then had lost legitimacy to nation-state. In this interpretation, empires were laid to rest by national movements that sought to liberate peoples and create their own national states. So, a nation-state is presented as the only adequate political form in the modern era. In full agreement with this approach, the collapse of the Soviet Union at the end of the 20th century was interpreted as the collapse of the "last empire."

All key elements of modernity-professional bureaucracy, industrialization, urbanization, mass alphabetization, complex and solid systems of physical and information communications, etc.emerged and developed, first and foremost, in empires. Parliamentary representation models were also originally created in imperial core countries-England and France. The idea of nation as the sole source of political legitimacy also arose in revolutionary France, which soon made the first attempt to establish European hegemony after the Roman Empire. The 19th and-to a large extent-the 20th centuries were a time of empires and nationalism. All major European and eventually non-European nations formed in empires. We are used to thinking that nations create empires, but in reality empires created nations (Kamen, 2004). These large nations emerged within the core of empires, and their elites did not seek to turn empires into culturally homogeneous nation-states or dissolve empires. On the contrary, they regarded the creation, preservation and, if possible, expansion of empires as a condition for successful development of the nations in their imperial centers (Berger and Miller, 2015).

Nationalist elites in the imperial centers viewed the empire as a nation-building resource. At the same time, they considered nationalism not only a "challenge from the peripheries," but also a resource for making their empires more competitive, provided it was the nationalism of imperial nations. They sought institutional and political solutions for building a nation in the imperial core and preserving the viability of the empire amid the growing inter-imperial rivalry in the world. In some cases (Spain, Portugal, Ottoman Empire, 
Denmark, Sweden), the efforts at nation-building in the core of empires had to be adapted to the circumstances caused by their decline and collapse, but in this case, too, imperial dynamics were the cause rather than the effect. It is not accidental that while losing colonies in America, both Portugal and Spain immediately sought to make up for that, at least partly, by acquiring new possessions in Africa. For Britain, France, Germany, and Russia, imperial expansion and nation-building were closely intertwined. The same can be said of Meiji-era Japan, which borrowed European imperial models to build a new state and create the emperor's cult as an embodiment of both the nation and the imperial mission (Fujitani, 1998).

The analysis of the specific experience of Germany and Italy also clearly shows the absolute prevalence of a "national narrative" in describing the formation of these states. However, the process of unification in many regions of Italy and Germany was generally viewed as subordination. Not only did the newly created states invoke imperial traditions for their legitimization, but they started competing for colonies almost immediately after unification, with Germany even attempting to undertake a large-scale expansion. In the latter case, the German nation's connection with the tradition of the Holy Roman Empire clearly manifested itself in the very name of the new state, Deutsches Reich, i.e. the German Empire. In Italy, the unification, which was not welcomed in some regions, was legitimized through an appeal to the virtues of the Roman Empire (romanita) and to the legacy of the Venetian Empire (venecianita). The German and Italian elites regarded imperial expansion as a way to consolidate the nation and join Europe's great powers. In other words, imperial motives were an important component of hegemonic unification.

All these factors suggest that the classical definition of nationalism given by Ernest Gellner, according to which the spaces of political and cultural control must coincide, is only partly relevant (Gellner, 1983, p.1.). It applies only to peripheral, separatist nationalism, which did not play a significant role in the 19th century. All known cases of successful separatist movements (mostly on the fringes of the Ottoman Empire) were due to the support from other empires, particularly Russia and 
Britain. The absence of such effective external support always led to a defeat, as in the case of the Bulgarian uprising of 1876.

\section{EMPIRE-STATE vS NATION-STATE}

A close look at the history of 19th century Europe shows that the most significant nation-building projects were carried out in the core areas of empires and were closely connected with the development of these empires and their place in the world system of inter-imperial rivalry. Nations were created by states, and empires supplied these states with resources. American historian Frederick Cooper proposed the concept of an 'empire-state' in order to stop the fallacious tradition of linking modernity statehood solely to nation-states (Burbank and Cooper, 2010). In the scenario of building imperial nations instead of a nation-state that consolidates the nation, we see an empire-state that builds a nation in its imperial core, but not necessarily a nation-state, and seeks to combine an imperial project with a national one. One of the key tasks of modern social sciences is to pay due attention to the connection between the imperial and the national and to finally get rid of the teleology of national narratives which prevailed throughout the 19 th and the first half of the 20th centuries.

Perceptions of the nation and empire in the long 19th century changed rapidly and simultaneously since they were closely intertwined. In Russia, the concepts of 'empire' and 'nation' made their way into the political lexicon at about the same time in the second decade of the 18 th century. Throughout almost the entire 18th century, there was no tension between them as they complemented each other, referring to sovereign polity. Another meaning of 'nation' that remained in effect until the early 19th century referred to a nobility corporation, which was consistent with the Polish concept of narod szlachecki ('szlachta nation') and the Hungarian concept of natio hungarica. By the late 18th century, the notion of 'nation' influenced by French experience appeared to be closely related to the concepts of national representation and constitution. In the 19th century, the concepts of 'nationality' and eventually 'nation' came into common use, and in the last two reigns, the monarchy actively used nationalism to legitimize its power. At the 
same time, the Russian nation was interpreted broader than just the Great Russians and included all of the empire's East Slavs and many of the Finno-Ugric groups and was open to assimilated members of many other ethnic communities living in the empire (Miller, 2016a, 2016b).

In Britain, the concept of 'nation' became part of the political vocabulary as early as in the Middle Ages, and the English nation firmly asserted itself as such in the 17th century. However, the notion of the British nation appeared only in the 18th century largely due to inter-imperial rivalry between Protestant England and Catholic France. In the 19th century, most of the Englishmen, who dominated Britain, were willing to melt their English identity into Britishness. In Germany, as early as the late 15th century, the words "of the German nation" began to be added to the name of the Holy Roman Empire. The notion of a nation was closely connected with that of empire, which sparked widespread imperial patriotism (Reichspatriotismus) in the 18th century. The Prussian design of the nation (kleindeutsch) won over the all-German design ( $g r o ß d e u t s c h$ ) following Prussia's victory over Austria in 1866, that is, it was the result of the struggle between the two empires. When the Austrian Germans had lost their empire after World War I, almost all of them were eager to support the new millenary Third Reich project proposed by Hitler.

United Germany clearly demonstrated its imperial ambitions not only in the struggle for overseas colonies, but also on the European continent. Its European expansion was largely inspired by the concept of Kulturboden (the idea of the cultural mission of Germans in Eastern Europe), and later by Lebensraum (the imperial-national idea of the German nation's living space). These examples of Russia, Britain, and Germany vividly show that in all the three cases, for all their differences, the nation and the empire were closely interconnected.

One of the key elements of nation-building is the "appropriation" of a certain territory as "national property." This is done in many ways such as demographic "conquest" through migration, discursive appropriation through historical narrative and literature, symbolic appropriation of territory through toponymics, fine arts and architecture. In expanding empires, national territory tended to 
expand as well but never covered the entire empire. Russia's imperial nation-building project was the most ambitious in terms of national territorial expansion. It included the appropriation of huge spaces in the empire's periphery as national territory, primarily through agricultural migration of millions of people, and successively covered the Volga region, Novorossiya, the North Caucasus, Siberia, and the Far East. In some cases, especially in the Caucasus, the migration of Russians to the region occurred simultaneously with the migration of non-Russians from the region, which today is one of the painful issues in the memory politics (see Miller, 2008).

Apart from the Great Russians, the Russian nation's project included Belarusians and Little Russians, as well as many Finno-Ugric ethnic groups. In Germany, the imperial nation project also required the Germanization of a large part of Prussian territories previously belonging to the former Polish-Lithuanian Commonwealth, and parts of Alsace after 1870, as well as selective assimilation of their residents. In both the Russian and German cases, national irredentism supported imperial claims to some territories outside the imperial borders. For example, Russia's claims to Red Ruthenia and Ugrian Russia, (today known as Galichyna and Trans-Carpathian regions of Ukraine) that is, part of the Austro-Hungarian Empire's possessions, were ideologically justified as "the gathering of the Russian lands." The same approach was used by Germany to justify its claims to Schleswig, Alsace, and later to the Baltic provinces of the Russian Empire. The difficult process of transforming the famous "hexagon" into the national territory of France, and turning the residents of Languedoc, Provence, and Brittany into Frenchmen, was far from completion in the early 20th century. Gradually, the French project crossed the sea to include Algeria. The exit from Algeria in the 1960s triggered a deep internal crisis in France. The construction of the British nation necessitated the unification of the Scottish and Welsh people with Englishmen for a joint mission of governing the giant empire. In the British case, the sea was not an insurmountable obstacle either: along with Scotland and Wales, some interpretations of the British nation project also included Ireland. Part of the British elites even insisted, just like John Seeley, on incorporating 
white communities of overseas colonists into the "greater" British nation, thus spreading the concept of national territory far beyond the British Isles. Needless to say, all four empires that carried out the most ambitious projects of building imperial nations belonged to the "supreme league" of European powers and empires that maintained the potential for further expansion (see Miller, 2003; Gammerl, 2010; Seeley, 1883; Weber, 1976).

Empires showed enormous resilience and mobilization potential during World War I, which was fundamentally new and total in nature. In that war, for the first time, the entire male population was considered a mobilization resource, and for the first time, the entire economy was put on a military footing. The empires collapsed after the titanic struggle that lasted more than four years, during which national movements augmented their potential mainly because the empires clashing in that all-out war had put considerable resources into supporting and strengthening separatist movements in the enemy camp. But even in this case national movements sought imperial patronage as a necessary condition for the more or less full implementation of their programs. The Great War forced the empires to use the double-edged sword of nationalism and ethnic separatism against each other and ultimately wrecked the macro-system of continental empires, which performed a certain stabilizing role, turning them into prey to history. After all, the war destroyed not only the weakened and shrinking Ottoman Empire stripped of economic sovereignty, not only the relatively less centralized Habsburg Empire which had experimented with ethnocultural autonomy, and not only the Russian Empire, economically lagging behind the West, torn apart by internal political contradictions, and short of time to consolidate new representative institutions and the imperial Russian nation. The German Reich also collapsed, even though the imperial nation and democratic institutions had largely been consolidated there, and its economic development had put it among the world's industrial leaders. So, regardless of internal strengths and weaknesses, none of the empires in Eastern Europe was able to survive World War I and the collapse of the interdependent macrosystem of continental empires. But even WWI did not become an event 
after which the age of empires and nationalism gave way to the age of nation-states.

Naturally, Wilson's and Lenin's anti-colonial ideologies threw down a serious challenge to empires. In his Fourteen Points published in January 1918, President Wilson suggested preserving both the Russian and Austrian and, even, the Ottoman Empires in some form (see paras. $6,10,12$ ). He understood the principle of national self-determination as a right to autonomy. With the collapse of imperial centers and the threat of socialist revolution, nationalizing states became a defense reaction to the crisis. In other words, it was the-socalled "default option," that is, an option selected in the absence of a better alternative. Virtually all states that emerged on the ruins of continental European empires were not national, but nationalizing, and suppressed national, ethnic and confessional minorities with varying degrees of brutality. Czechoslovakia and the Kingdom of Serbs, Croats and Slovenes emerged as composite, multicomponent states.

\section{EMPIRES IN THE 20TH CENTURY: OLD AND NEW}

During the interwar period, the Soviet Union and the Third Reich made attempts to recreate imperial structures in new forms, fundamentally different from each other. The British and French Empires existing since pre-war times were nearby. Outside interbellum Europe, distinct imperial traits were evident in the United States and Japan.

The Soviet project was not only fundamentally different from the Russian Empire, but consciously rejected it. As early as the 19th century, one of the key elements of the Russian Empire's ideology and policy was the "greater Russian nation" project, which was supposed to unite Great Russians, Little Russians, and White Russians (Belarusians). The last third of the 19th century saw marked nationalization of the ruling dynasty, which kept emphasizing its Russianness. Assimilation processes were welcomed and encouraged. Ethnicity was not institutionalized since the authorities adhered to the formal classification by faith and language. Unlike the Austro-Hungarian army, the Russian army did not have units organized along ethnic lines. 
The Soviet project of gathering the space formerly belonging to the Russian Empire was inspired by completely different ideas: 1) "Great Russian chauvinism" as the main threat to Soviet power; 2) denial of the all-Russian nation concept and recognition of Ukrainians and Belarusians as separate nations, with the creation of corresponding Soviet republics; 3 ) institutionalization and regularization of ethnicity; 4) nation-building as a necessary stage in the development of local communities on the way to socialism; 5) positive discrimination of non-Russians as compensation for Russian dominance in the Russian Empire. This approach was implemented through indigenization, which envisaged active efforts to dismantle the successes achieved as part of the previous policy of building an imperial nation, as well as through the creation of a colossal pyramid of national republics, autonomous republics, districts, etc. At the height of indigenization, there were about 10,000 such ethno-territorial units. Although many elements of this policy, especially the fight against "Great Russian chauvinism," were abandoned in the early 1930s, its key guidelines remained in place thereafter (Martin, 2001).

It was not until World War II, in which the "young" German and Japanese empires suffered defeat, ended and the United States became able to dictate conditions to its weakened Western allies after the war that the French and British Empires were dismantled and the period which Jürgen Osterhammel called a "century of empires and nationalism" (Osterhammel, 2009) came to an end.

However, this does not mean that the age of empires ended with World War II. The entire 20th century was a time of experimentation to find new combinations of nationalism and empire. These included the radically hierarchical, racially based Nazi project; the Soviet "empire of positive action," which in the final decades of its existence tried to form the Soviet people as "a fundamentally new historical community;" and the American post-war version of liberal empire, which won the Cold War. These experiments also included the European Union, which relied heavily on the legacy of the Holy Roman Empire and of AustriaHungary, which combined the imperial form with local autonomy (Zielonka, 2006). 
Outside Europe, the "organic" process of building nation-states was seen only in Latin America, where the Spanish Empire's provinces threw off its rule in the 18th century (Anderson, 1991). In the 20th century, decolonization in Southeast Asia, the Middle East, and Africa led to the emergence of a number of states which more or less diligently imitated nation states. But only a few match, if only roughly, the European-style nation-state model.

A nation-state became a norm in Europe after World War II, largely due to genocide, forced relocation of large numbers of people, and border redrawing. After the war, Western European states were under the care of NATO and later, in part, the EU, while Eastern European states were under the care of the Soviet Union as part of the Warsaw Pact and COMECON. For four decades, the two systems prevented territorial conflicts between their members and kept modern borders intact. After the collapse of the Eastern bloc, and eventually the USSR itself, most of the former socialist countries started seeking protection and external guarantees of stability, eventually finding them in NATO and the EU. Those who failed to do so experienced, and are still experiencing, serious difficulties. Almost all of the post-Soviet states, including the new Baltic members of the $\mathrm{EU}$, are nationalizing states, with clear signs of discrimination against minorities or their expulsion.

An attempt to assess the limits of the nation-state as a political model within the liberal theory was made by Juan Linz and Alfred Stepan, who proposed the "state-nation" model as better matching the situation where there are two (or more) large groups of population in a country politically mobilized as nations. These experts believe that attempts to pursue an aggressive nation-state policy and claims to the exclusive right to state formation in such countries is likely to heighten inter-ethnic tensions (Stepan, 2005; Stepan, Linz and Yadav, 2011). There are a number of examples, including Ukraine and Georgia, proving this. Russia's interference as the heir to the empire to which these states belonged once, in full compliance with 19th century scenarios, prevented the central authorities from suppressing resistance to nation-state policies in these countries. What makes the approach 
offered by Linz and Stepan so valuable is that it draws attention to the fact that heterogeneous polities have developed other forms and institutional arrangements different from the nation-state.

In the current global situation, when unpredictability in international relations has increased dramatically, the wave of globalization that continued for thirty years has died out, and the optimistic vision of the future has become a sign of thoughtlessness, many tend to act stereotypically in hard-to-anticipate crisis situations-people try to lean on something familiar, seemingly reliable and proven. This explains the widespread illusion of reemerging nationalism and return to the nation-state. This trend will not last long because reliance on the nation-state cannot produce the desired effect when that state is small. We will soon be seeing how vulnerable and volatile such small nation-states become when external stabilizers stop working.

\section{THE LEGACY OF EMPIRES}

\section{AND ITS SIGNIFICANCE FOR MODERN RUSSIA}

Modern Russia has to deal with the extremely complex and contradictory legacy of two empires on the ruins of which the Russian Federation has emerged. This situation is unique in many ways. It resulted from seventy years of communist policy to implement the imperial project on the principles which were explicitly and consciously pit against the pre-revolutionary project of imperial development (see Miller, 2007). It was also the result of the defeat in the Cold War and of the establishment revolution, when much of the Soviet legacy remained in place. This was fundamentally different from the situation of the World War II losers, Germany and Japan, where the legacy of their 20th-century imperial projects was harshly bulldozed by the winners. It would have been wrong to assume that the processes following the collapse of the USSR would sweep away the remains of the imperial legacy, similarly to how it was done in Germany and Japan. The case of Russia as a nuclear power, which will remain untouchable in the immediate future, is unique as is the transformation of its imperial legacy, that is, not predictable "by analogy." 
1) Soviet legacy remains in many institutions, above all in ethnic autonomous territories. As a result of the Soviet policy of institutionalization and territorialization of ethnicity, a number of "titular" ethnic groups firmly identify themselves as nations and the owners of their republics' territory as "national territory." These republics have a number of ethnic institutions inherited from the USSR. The ethnic key remains important for getting access to senior positions in these autonomies. This makes it extremely difficult, or in stronger terms, almost impossible, to create a classical nation-state with a single nation. But this does not mean that Russia's spatial organization cannot change. However, this process will take a long time, and it should not aim at forming a typical European nation-state in this part of the world.

Any changes in this sphere may cause serious complications. The reduction of ethnic privileges in autonomies after the collapse of the Soviet Union means that their politically active representatives perceive the trends concerning "ethnic rights" as negative. It is wellknown though, that the level of dissatisfaction in certain groups is determined not so much by the number of rights available as by how trends reflecting changes are perceived, namely, whether the range of rights and privileges is expanding or shrinking.

Meanwhile, about 80 percent of Russia's population consider the autonomy situation unfair and rooted in anti-Russian Soviet politics. Plans to build a Russian nation remind them of the Soviet people project, which "dissolved" Russianness in Sovietness. The view that the pre-revolutionary empire was "the right legacy" is quite popular among Russians. It is not accidental that Alexander Solzhenitsyn's Rebuilding Russia, in which the author frankly appealed to the image of the Russian national territory known before the collapse of the Romanov Empire, evoked such strong response after its publication in 1990 and still does today.

It should be noted that almost no one recalls the Soviet institutional legacy of nationalities policy as a positive and valuable experience; all ethnic groups have developed a narrative of oppression. The Soviet legacy in the institutional landscape of modern Russia does not suit 
anyone but appeals to the Russian legacy are no more than an attempt to lift Atlantis, because this legacy was institutionally buried by the Soviet project.

2) The legacy of empires is a very complex challenge that makes simple solutions impossible. First of all, attempts to take revenge, that is, restore the Soviet empire, are invariably doomed to failure. And yet this temptation can be discerned in the political imagination of some people, and Vladimir Putin's well-known statement, which his critics often refer to as a revanchist one, was in fact a warning against such attitudes. He said not only that those who did not regret the collapse of the Soviet Union had "no heart," but also that those who wanted to restore the Soviet Union had "no mind."

The second simple approach would be a straightforward urge to build a nation-state in Russia, that is, to act as if there is no imperial legacy at all or it can be disposed of in one go. However, Russia has inherited more than twenty autonomous ethnic republics from Soviet nationalities policy. The titular population of at least some of these republics is politically mobilized, which means that it has a distinct national identity and views "their" republic as their own national territory. Sometimes this image of national territory transcends the borders of a republic, provoking interethnic conflicts and tensions. (See, for example, events around the Prigorodny District in North Ossetia, or recent border regulation incidents between Chechnya and Ingushetia.) A nation-state suggests that there is only one group in it, it is mobilized as a nation and perceives the state as its own. All the other groups may be treated worse or better, but they are considered minorities and cannot claim this state as their "property."

Political science offers a variety of models that attempt to describe different ways to organize the state, taking into account the presence of two or more politically mobilized nations within one state. The "nation-state" and "state-nation" dilemma proposed by Juan Linz and Alfred Stepan is the best known of all. Earlier, Arend Lijphart (2004) wrote about "consociational" democracy. At any rate, trying to claim that there is a supra-ethnic Russian (Rossiiskaya) nation in Russia, which includes all citizens of the country, would be a simplification 
fraught with very serious problems. These problems will be exacerbated by active nationalizing policies designed to transform reality in a manner consistent with the declared reality in which there is no conflict between the "Russian nation" and mobilized ethnic nations in autonomous republics.

In addition, it is necessary to acknowledge a conflict between the Russian nation concept and those supporters of the Russian national identity who view the "Russian (Rossiiskaya) nation" as a new edition of the "Soviet people" concept which dissolved Russianness. In the current situation, an attempt to turn Russia into a nation-state with a united Russian nation would mean denying the significance of the imperial legacy. However, the contradictions described above can be made less severe if we admit that the imperial legacy is important and requires a search for more complex forms of organizing the Russian state than a "nation-state."

3) The imperial legacy affects our approaches to a range of very important issues and even to politics in general. For example, we can say with confidence that Russian elites have historically given priority to foreign policy over domestic policy. This is typical of the elites of great powers, which in the middle of the 19th century spent more than half of the state budget on military needs even in peacetime. In fact, in building its foreign policy Russia is still guided by the considerations of prestige and the need to defend the status of great power.

Is a different approach to foreign policy, the one that will prioritize internal development, possible? Russia's place in the league of great powers is determined by the Soviet empire's legacy, that is, by the seat in the UN Security Council inherited from the Soviet Union and its military, mainly nuclear, capabilities. Would it be possible to retain this status in the long term without qualitative changes in the dynamics of internal development? This will become clearer if we assess the dynamics of development in the post-Soviet period, which by now has resulted not only in the loss of Russia's influence in most of the countries that emerged after the collapse of the Soviet Union, but also in the disintegration of the Slavic core of the three republics that signed the treaty on the dissolution of the USSR. 
A transition from the priority of foreign policy to the priority of internal development implies a significant reevaluation of the country's role in the world and its importance in international relations. In general, it is part of a bigger problem requiring the country's political elites to come to terms with changes in its scale. For now, this problem is far from being solved.

4) Another important example of how difficult it is to understand the changed role and place of the country in the world, particularly in the near abroad, is the attitude to the fate of Russians who found themselves outside of Russia after the collapse of the USSR. In a number of cases, Moscow sought to keep Russians where they lived not because it cared about their interests but because it viewed the Russian communities there as a tool for projecting influence to former Soviet republics. This position reflected the hope for a reversal of the general trend towards the disintegration of imperial space in favor of post-imperial reintegration. Today one can say with confidence that the integration efforts have failed, and will not be able, to change the general trend. The unwillingness to admit this largely stems from the imperial legacy and the related intellectual inertia.

One of the possible answers to this situation is irredentism. This concept means a policy of the state or another political actor to unite the people, the nation, or an ethnic group within one state. A version of irredentism combined with imperial territorial expansion was exercised by Italy and Germany in the 19th century and by Germany in the first half of the 20th century. But this type of irredentism may have unpredictable and severe consequences for Russia. Russia has so far achieved very modest progress in exercising the kind of irredentism that Germany demonstrated after World War II, when the country "was gathering" people without territories.

Given the reincorporation of Crimea and the situation in a number of unrecognized republics, we can argue that Russia has so far shown "omnivorousness" and inconsistency in irredentist politics, which is directly related to the contradictory approach to the legacy of empires.

5) The post-imperial state of modern Russia reveals several important political principles: 
- the impossibility of return to the previous imperial scale (whatever is chosen as the "golden age");

- the necessity to rethink the size of the country, its capabilities and future, as well as the place of Russia in the world;

- the post-imperial complex of modern Russia that clearly indicates that the legacy of empires, i.e. the "ruins" of former empires, tangibly permeates Russia's modern life, its intellectual, institutional, and other dimensions. Attempts to ignore this legacy or drastically "clear out the ruins" will not yield positive results;

- the task to create a design of the future in which its authors can take an unbiased look at the legacy of empires, free from the inherited intellectual restrictions and hackneyed stereotypes, and at the same time will be able to fit the imperial legacy (for example, the consensus on sovereignty as an unquestionable value) into the image of post-imperial Russia's future.

\section{References}

Anderson, B.R., 1991. Imagined Communities: Reflections on the Origin and Spread of Nationalism. Revised and extended edition. London: Verso.

Berger, S. and Miller, A. (eds.), 2015. Nationalizing Empire. Budapest, CEU Press.

Burbank, J. and Cooper, F., 2010. Empires in World History: Power and the Politics of Difference. Princeton: Princeton University Press.

Fujitani, T., 1998. Splendid Monarchy: Power and Pageantry in Modern Japan. Berkeley: University of California Press, pp.1-28, 197-229, esp. p.24.

Gammerl, B., 2010. Untertanen, Staatsbürger und andere. Der Umgang mit ethnischer Heterogenität im britischen Weltreich und im Habsburgerreich 18671918 [Subjects, Citizens and Others. Dealing with Ethnic Heterogeneity in the British Empire and the Habsburg Empire]. Göttingen: Vandenhoeck \& Ruprecht.

Gellner, E., 1983. Nations and Nationalism. Ithaca: Cornell University Press.

Kamen, H., 2004. Empire: How Spain Became a World Power, 1492-1763. New York: Perennial. 
Lijphart, A., 2004. Constitutional Design for Divided Societies. Journal of Democracy, 5(2), pp.96-109.

Martin, T., 2001. The Affirmative Action Empire: Nations and Nationalism in the Soviet Union, 1923-1939. Cornell University Press.

Miller, A, 2008. The Romanov Empire and Nationalism. Budapest: CEU Press.

Miller, A. 2003. The Ukrainian Question. Budapest: CEU Press.

Miller, A., (ed.), 2007. Nasledie imperiī i budustchee Rossii [Empires' Legacy and Russia’s Future]. Moscow: NLO.

Miller, A., 2016a. Istoriya poniatiya Natsiya v Rossii [The History of the Notion of Nation in Russia]. In: Miller, A., Sdvizhkov D. and Schierle, I. (eds.). Poniatia $o$ Rossii [Notions on Russia]. Vol. 2, 7-49, Moscow: NLO.

Miller, A., 2016b. Natsiya, ili mogustchestvo mifa [Nation, or the Might of The Myth]. SPb: EU Press.

Osterhammel, J., 2009. Die Verwandlung der Welt. Eine Geschichte des 19. Jahrhunderts [The Transformation of the World. A Story of the 19th Century]. Munich: Beck.

Seeley, J. R., 1883. The Expansion of England. London: MacMillan.

Stepan, A., 2005. Ukraine: Improbable Democratic "Nation-State" but Possible Democratic "State-Nation”? Post-Soviet Affairs, 21(4), pp.279-308.

Stepan, A., Linz, J.J. and Yadav, Y., 2011. Crafting State-Nations: India and Other Multinational Democracies. Johns Hopkins University Press.

Weber, E., 1976. Peasants into Frenchmen. The Modernization of Rural France, 1870-1914. Stanford: Stanford University Press.

Zielonka, J., 2006. Europe as Empire: The Nature of the Enlarged European Union. Oxford: Oxford University Press. 